\title{
Expression of neuroendocrine markers in endometrial carcinomas - an immunohistochemical analysis
}

\author{
Witold Kędzia ${ }^{1}$, Andrzej Kędzia² ${ }^{2}$ Helena Rajpert-Kędzia ${ }^{3}$ \\ ${ }^{1}$ Department of Gynecology and Obstetrics, Poznan University of Medical Sciences, Poznan, Poland \\ ${ }^{2}$ Department of Clinical Auxology and Pediatrics Nursing, Poznan University of Medical Sciences, \\ Poznan, Poland \\ ${ }^{3}$ Pathological Laboratory, Gynecology and Obstetrics Hospital, Poznan University of Medical \\ Sciences, Poznan, Poland
}

\begin{abstract}
The main aim of this study was the analysis of undifferentiated cancers and mixed ones positive for neuroendocrine biomarkers without morphological features - typical for this type of cancer. The obtained results indicated the necessity for neuroendocrine marker tests in undifferentiated cancers and mixed ones. Immunopositive results revealed enhanced malignancy of these cancers and the necessity for additional chemotherapy. (Folia Histochemica et Cytobiologica 2012, Vol. 50, No. 2, 280-285)
\end{abstract}

Key words: immunohistochemical cell markers, neuroendocrine markers, endometrial carcinomas

\section{Introduction}

Besides the endocrine system, the human body is equipped with a heterogenic group of neuroendocrine cells (Diffuse Endocrine System - DES) distributed all over the organism. The 'APUD cell' (amine-precursor uptake and decarboxylation system) hypothesis formulated by Pearse says that these cells are not only able to gather amines, but can also uptake amine precursors and transform them into amines through the intracellular decarboxylation process [1]. Two types of secretory granules were isolated from the cytoplasm of neuroendocrine cells: big granules with electrondense material in the core part, and microvesicles similar to presynaptic vesicles of the nervous system $[1,2]$. They ectopically produce endocrine non-hormonal biomarkers, biogenic amines and various polypeptide hormones [3-6]. In the endometrium, pure neuroen-

\footnotetext{
Correspondence address: W. Kędzia,

Department of Gynecology and Obstetrics,

Division of Gynecological Oncology,

Poznan University of Medical Sciences,

Polna Str. 33, 60-535 Poznan, Poland;

e-mail:witold.kedzia@poczta.fm
}

docrine cancers are very rare, and are more frequently recognized in the ovaries and uterine cervix [7-12].

Recently, articles have been published about the coexistence of undifferentiated cancers, serous and endometrioid, with focal positive immunoreactions for one or more neuroendocrine markers without morphological transformation into neuroendocrine cancer [5, 13-17]. This phenomenon is not well known and needs additional studies.

The aim of this study was to assess neuroendocrine cells in endometrial cancers with regard to their number, origin, localization and morphological picture. The obtained results were related to the type of cancer, the degree of differentiation, and the stage of development. Additionally, the effect of neuroendocrine markers on cancer malignancy in the presence of immunopositive cells was determined.

\section{Material and methods}

Twenty endometrial cancers including three undifferentiated cancers (G3), two serous carcinoma (G2), three partially undifferentiated partially endometrioid carcinoma, and 12 endometrioid adenocarcinoma (seven in G1 and five in G2 stage) were studied. In all patients, a uterectomy with uterine adnexa was carried out; lymphadenectomy of the 
Table 1. Immunohistochemical staining profile for eight studied cancers

\begin{tabular}{|c|c|c|c|c|c|c|c|c|c|}
\hline & Cancer type & $\begin{array}{l}\text { Cytokeratin } \\
\text { AE1/AE3 }\end{array}$ & Vimentin & Chromogranin & Synaptophysin & NSE & PR & CD117 & Desmin \\
\hline 1. & $\begin{array}{l}\text { Undifferentiated } 40 \% \\
\text { Endometrioid } 60 \%\end{array}$ & $\begin{array}{l}- \\
+\end{array}$ & $\begin{array}{l}- \\
+\end{array}$ & $\begin{array}{c}++ \\
+\end{array}$ & $\begin{array}{c}++ \\
+\end{array}$ & $\begin{array}{l}+ \\
-\end{array}$ & $\begin{array}{c}- \\
+++\end{array}$ & $\begin{array}{l}- \\
-\end{array}$ & \\
\hline 2. & $\begin{array}{l}\text { Undifferentiated } 30 \% \\
\text { Endometrioid } 70 \%\end{array}$ & $\begin{array}{l}+ \\
+\end{array}$ & $\begin{array}{l}- \\
-\end{array}$ & $\begin{array}{c}++ \\
-\end{array}$ & $\begin{array}{l}+ \\
-\end{array}$ & - & $\begin{array}{l}- \\
++\end{array}$ & - & \\
\hline 3. & Undifferentiated & + & - & +++ & +++ & + & - & - & - \\
\hline 4. & Undifferentiated & + & - & +++ & +++ & + & - & - & \\
\hline 5. & Serous & + & - & ++ & - & - & + & - & \\
\hline 6. & Undifferentiated & + & - & - & - & - & + & - & \\
\hline 7. & $\begin{array}{l}\text { Undifferentiated } 40 \% \\
\text { Endometrioid } 60 \%\end{array}$ & $\begin{array}{l}+ \\
+\end{array}$ & $\begin{array}{l}- \\
-\end{array}$ & $\begin{array}{l}- \\
-\end{array}$ & $\begin{array}{l}- \\
-\end{array}$ & $\begin{array}{l}- \\
-\end{array}$ & $\begin{array}{l}- \\
++\end{array}$ & $\begin{array}{l}- \\
-\end{array}$ & - \\
\hline 8. & Serous & + & - & - & - & - & + & - & \\
\hline
\end{tabular}

+++ strong expression; ++ intermediate expression; + weak expression

pelvis was done in two patients. In some patients, radiotherapy was applied and, additionally, chemotherapy was included in three other patients. The characteristics of the study group are set out in Table 1.

In addition, three normal fetal uterus, five normal endometrium (two secretory, three proliferative phase) and four endometrium with pathological hyperplasia were studied. In all the 20 cancerous and additionally collected material, immunohistochemical analysis was done for the presence of neuroendocrine markers such as chromogranin A, synaptophysin and neuron-specific enolase (NSE). Moreover, staining for the presence of progesterone receptor (PR), which determines the degree of differentiation of endometrioid cancers, was done. In addition, staining for cytokeratin (AE1/AE3), vimentin, CD117, and desmin was carried out. Immunoreaction was carried out with the horseradish peroxidase (HRP) system, EnVision ${ }^{\mathrm{TM}+}$ (Dako, Poland).

Some antibodies (Dako, Poland) were used in the following dilutions: 1:50 vimentin, 1:200 NSE, 1:400 CD117. Remaining antibodies were bought in ready-to-use concentrations. Anti-chromogranin A, anti-synaptophysin and antiCD117 antibodies were polyclonal, and the remaining antibodies were monoclonal. The negative control was the omission of the first antibody. In the assessment of neuroendocrine markers expression, an additional control was tissue section from endocrinal carcinoma positive for three neuromarkers.

\section{Results}

Five out of eight low-differentiated cancers needed special attention. Those cancers were placed in the first five positions in Tables 1 and 2. The first of them (No. 1) was diagnosed as adenocarcinoma endometrioides partim solidum. In $\mathrm{H}+\mathrm{E}$ staining, this well- -differentiated endometrioid cancer included almost the whole endometrium (60\% of tumor area), whereas undifferentiated solid pattern infiltrated muscle wall of uterus. Metastasis to lymph nodes only consisted of undifferentiated solid constitutions, and embolism from these cells occurred in vessels. In immunohistochemical staining, cancer infiltrating myometrium was immunopositive for all neuroendocrine markers; whereas in endometrioid structure, positive reaction was found only in single multi-cell nests (Figure 1). Immunopositive reaction for PR was negative in undifferentiated cancer and strongly positive in endometrioid adenocarcinoma.

In the second case (No. 2), two pictures were observed: solid undifferentiated contained $30 \%$ of the tumor area, while the remaining $70 \%$ was represented by endometrial carcinoma. Solid growth pattern mainly infiltrated muscle wall of uterus; however, solid and glandular structures were observed more often in single focus compared to tumor No. 1. Poorly differentiated types were immunopositive for chromogranin A and synaptophysin, and negative for NSE (Figure 2). Progesterone receptor was stained positively in adenocarcinomatoid typing. Carcinoma solidum undifferentiatum was diagnosed in cancers No. 3 and 4. In both cancers, positive reaction for three neuroendocrine markers was observed. However, in cancer No. 3, the reaction occurred only in single cells spread throughout the whole tumor; the highest positive focus did not exceed 1.0-2.0 mm. In cancer No. 4, immunopositive reactions contained areas exceeding as much as $0.5-1.5 \mathrm{~cm}$. Both cancers were negative for PR. In the histological picture, huge attention was concentrated on cellular atypia, high mitotic activity, infiltration of vessels as well as extensive necrosis. 
Table 2. Characteristics of studied cancers

\begin{tabular}{|c|c|c|c|c|c|c|c|}
\hline No & Age & Cancer type & $\begin{array}{c}\text { Differentiation } \\
\text { "G" }\end{array}$ & Stage & Metastasis to nodes & Treatment & $\begin{array}{l}\text { Survival } \\
\text { (months) }\end{array}$ \\
\hline 1. & 63 & $\begin{array}{c}\text { Undifferentiated } 40 \% \\
\text { Endometrioid } 60 \%\end{array}$ & $\begin{array}{l}3 \\
1\end{array}$ & IIIc & $\begin{array}{l}+ \\
-\end{array}$ & $\begin{array}{c}\text { RTG } \\
\text { Chemotherapy }\end{array}$ & $\begin{array}{c}6 \\
\text { dead }\end{array}$ \\
\hline 2. & 57 & $\begin{array}{c}\text { Undifferentiated } 30 \% \\
\text { Endometrioid } 70 \%\end{array}$ & $\begin{array}{l}3 \\
2\end{array}$ & Ic & - & RTG & $\begin{array}{c}18 \\
\text { relapse in lungs }\end{array}$ \\
\hline 3. & 49 & Undifferentiated & 3 & $\mathrm{IIb}$ & - & RTG & 8 \\
\hline 4. & 58 & Undifferentiated & 3 & $\mathrm{IIb}$ & - & Chemotherapy & 1 \\
\hline 5. & 61 & Serous & 2 & IIa & - & RTG & 10 \\
\hline 6. & 79 & Undifferentiated & 3 & IIIa & - & RTG & 3 \\
\hline 7. & 59 & $\begin{array}{c}\text { Undifferentiated } 40 \% \\
\text { Endometrioid } 60 \%\end{array}$ & $\begin{array}{l}3 \\
1\end{array}$ & $\mathrm{Ib}$ & - & RTG & 1 \\
\hline 8. & 71 & Serous & 2 & IIIa & - & $\begin{array}{c}\text { RTG } \\
\text { Chemotherapy }\end{array}$ & 51 \\
\hline 9. & 64 & Endometrioid & 2 & IIIa & + & RTG & $\begin{array}{c}4 \\
\text { dead }\end{array}$ \\
\hline 10. & 58 & Endometrioid & 1 & Ic & - & - & 5 \\
\hline 11. & 78 & Endometrioid & 1 & Ic & - & - & 4 \\
\hline 12. & 48 & Endometrioid & 2 & $\mathrm{Ib}$ & - & RTG & 6 \\
\hline 13. & 57 & Endometrioid & 1 & Ia & - & - & 5 \\
\hline 14. & 60 & Endometrioid & 2 & $\mathrm{IIb}$ & - & RTG & 5 \\
\hline 15. & 60 & Endometrioid & 2 & IIIa & - & RTG & 4 \\
\hline 16. & 48 & Endometrioid & 1 & $\mathrm{IIb}$ & - & - & 7 \\
\hline 17. & 52 & Endometrioid & 1 & Ia & - & - & 7 \\
\hline 18. & 60 & Endometrioid & 1 & $\mathrm{Ib}$ & - & - & 5 \\
\hline 19. & 61 & Endometrioid & 1 & $\mathrm{Ib}$ & - & - & 5 \\
\hline 20. & 53 & Endometrioid & 1 & $\mathrm{Ib}$ & - & - & 7 \\
\hline
\end{tabular}

Cancer No. 5 is represented by serous cancer infiltrating the whole wall of uterus as far as serous membrane. Numerous emboli from cancer cells were visible in vascular lumen. In immunohistochemical staining, a high expression of chromogranin A was observed in foci infiltrating uterus wall and in vascular lumen, whereas immunoreaction was significantly weaker in the remaining pattern. Two remaining neuroendocrine markers were negative. Immunoreaction for the presence of progesterone receptor occurred focally, and only in a small number of cells localized in foci of infiltration.

In three other cancers (Nos. 6, 7, 8) neuroendocrine markers were not observed. In the remaining 12 endometrioid moderately differentiated and highly-mature cancers, the presence of disseminated endocrine cells of APUD type was noted. They demonstrated only positive reaction on chromogranin A. They were located in a basal part of glandular cells or the immunopositive material was localized in an apical part of glandular cells (Figure 3).
In pathological hyperplasia of endometrium, 1-3 chromogranin positive cells were observed for ten small magnifications, while in normal and fetal endometrium it was $0-1$.

In fetal uterus, single epithelial cells were immunopositive only for chromogranin A.

\section{Discussion}

The degree of differentiation of endometrioid cancers is considered to be one of the key prognostic factors. Five-year survival rate of women with G1 cancer being in $\mathrm{I}^{\circ}$ progression is estimated at $92.1 \%, \mathrm{G} 2$ at $87.5 \%$ and $\mathrm{G} 3$ at $74.5 \%$ [18]. The less differentiated the cancer and the deeper the infiltration of the uterus wall, the poorer the prognosis. Poorly differentiated and undifferentiated endometrial cancers comprise $2 \%$ of all endometrial cancers and frequently create mixed cell populations with different prognoses $[3,5,13-16,19]$.

In our studies, immunopositive reactions were recorded for three neuroendocrine markers in five out 

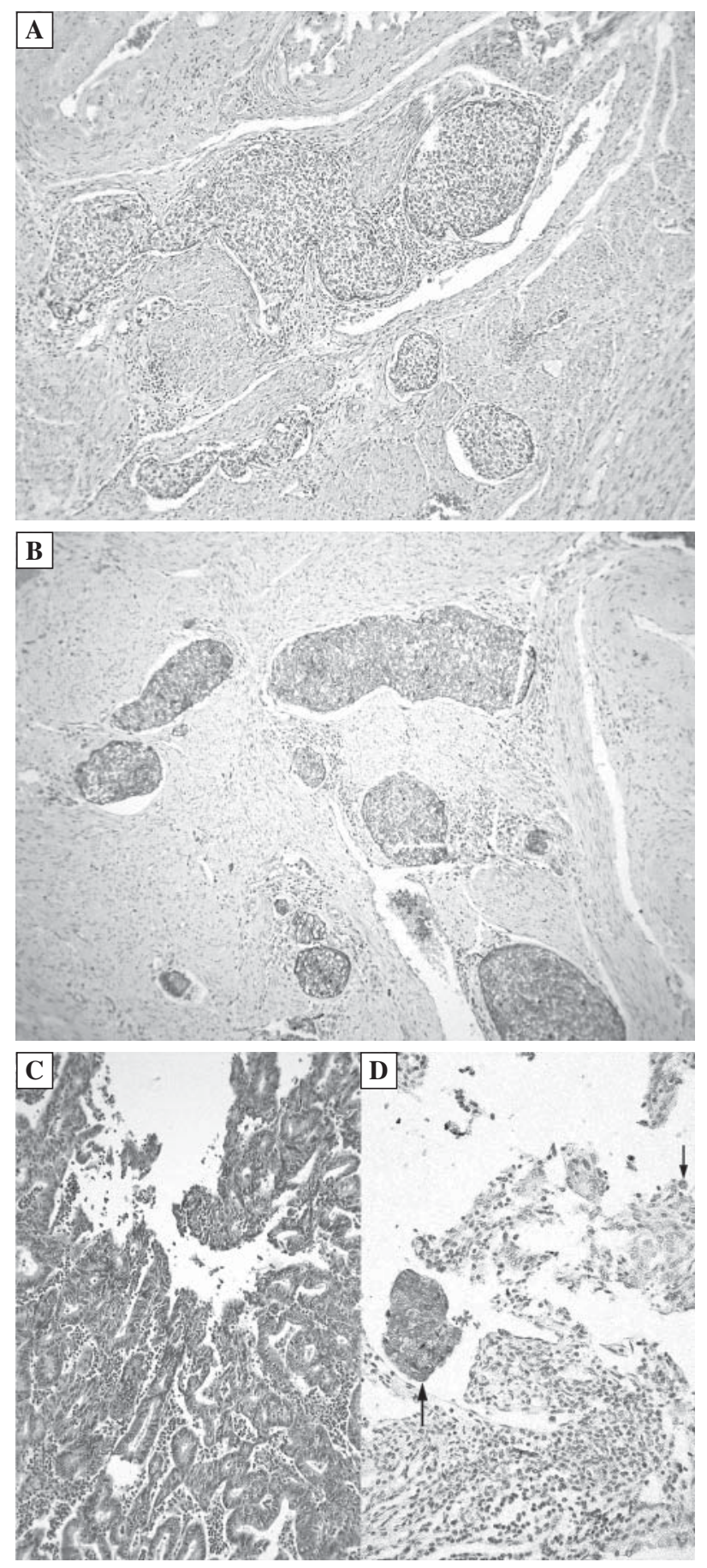

Figure 1. Cancer with two different patterns (position No. 1 in Tables). Solid undifferentiated pattern infiltrating muscle wall of uterus, $\mathrm{H}+\mathrm{E}$ staining (A); Following sections stained for synaptophysin (B); Endometrioid portion, $\mathrm{H}+\mathrm{E}$ staining (C); Following section stained for synaptophysin (D). Nest of cells and single cell immunopositively stained (arrow) (magnification $\times 150$ )

of eight undifferentiated cancers and with mixed cell population. The remaining three cancers were neuroendocrine negative. Therefore, a question appears

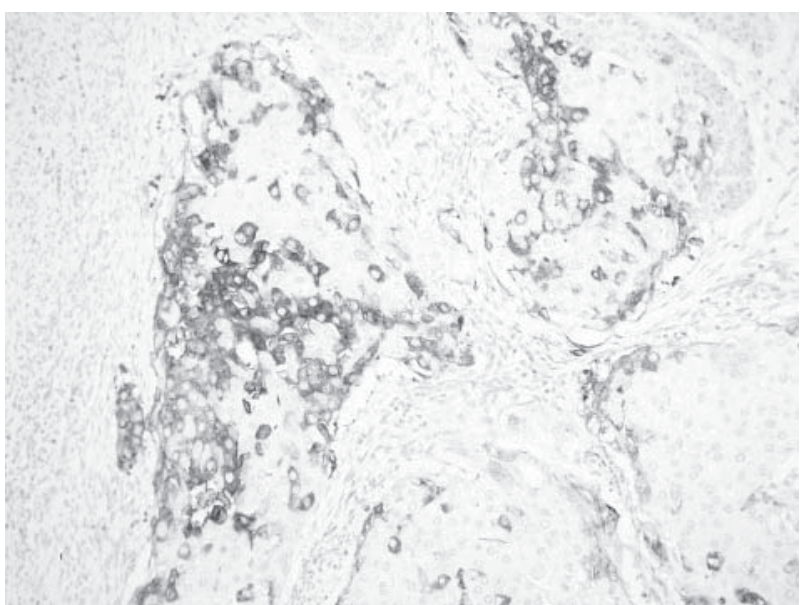

Figure 2. Undifferentiated cancer immunoreaction for synaptophysin $($ magnification $\times 250)$

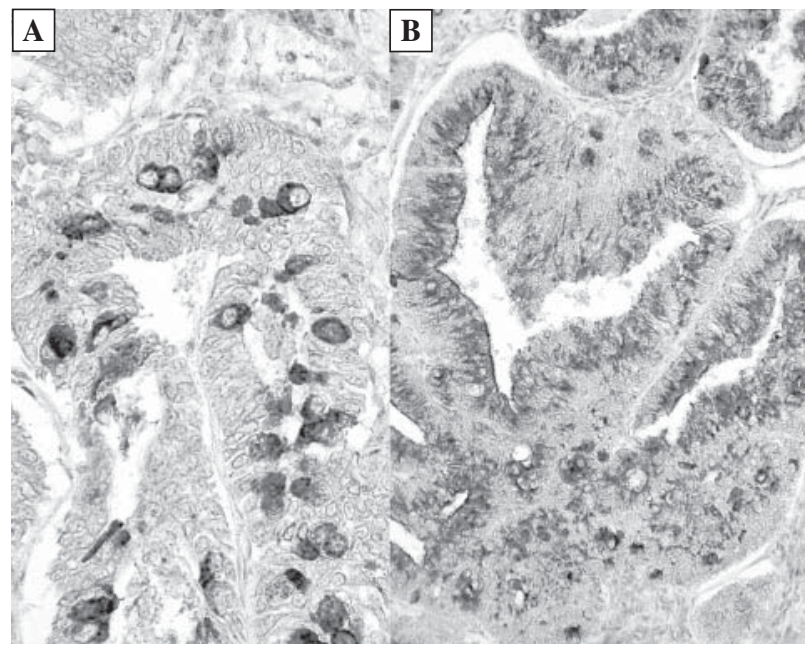

Figure 3. Cells DES type in endometrial carcinoma, positive for chromogranin A. Localized in glandular basal region (A) and in the apical part of cells $(\mathbf{B})$

$($ magnification $\times 350)$

as to how we should interpret these cancers, especially as a prognostic factor. A large heterogeneity between undifferentiated cancers causes serious diagnostic and therapeutic problems since they contain cancers of differing aetiology. Lung or cervical smallcell carcinoma with neuroendocrine differentiation are considered as aggressive carcinomas. It might be assumed that neuroendocrine differentiation is a potential marker for aggressiveness. Recently, more attention has been concentrated on the fact that undifferentiated endometrial carcinomas can possess immunopositive reactions for neuroendocrine markers without typical morphological features of neuroendocrine carcinoma $[5,14,17]$. Tamura et al. showed 
positive reactions for neuroendocrine markers at $63 \%$ of undifferentiated cancers without typical morphological features [14]. In immunoreaction, single cells localized in nests were stained or reaction had diffusion character.

In our material, one out of two serous carcinomas was diffusion stained for the presence of chromogranin A with increased expression in foci of infiltrates of muscle wall, and negative for the remaining two markers. However, in two other undifferentiated cancers, all three neuroendocrine markers were positive. Their morphological picture indicated high histological malignancy, but was not typical for neuroendocrine cancers. However, in two mixed cancers, neuroendocrine solid pattern with atypical structure for this type of cancer deeply infiltrated uterus muscle wall; endometrioid pattern constitutions were limited to the endometrium. Similar morphological pictures have been frequently described in the literature $[4,5,13,14,18,20,21]$. Histogenesis of such cancer pattern is not clear. There is no consensus as to whether they are two independent cancers, or we are witnessing a cancer with mixed cell population. The small foci of neuroendocrine carcinomas localized within endometrial carcinoma, and clinical studies excluding cancer outside the uterus, give the answer as mixed cell carcinoma. It has been suggested that populations of both cell types have originated from the same stem cell [22]. Cancer stem cells go through asymmetrical division, which induces tumorogenesis from one side and, from the other, some number of progenitor cells keep the ability to differentiate and mature, providing phenotypic heterogeneity. Therefore, various clones of cancer cells can, in different ways, be phenotypically shaped dependent on various pathological signal pathways and genetic programs. This phenomenon also seems to explain the occurrence of positive neuro-immunoreactions in cells, which morphologically did not fit for neuroendocrine cells. It could be that changes related to morphological transformations did not follow cell biochemistry.

The three commonly used neuroendocrine biomarkers for isolated neuroendocrine cancers have different specificities. Synaptophysin is an integral membrane glycoprotein isolated from presynaptic vesicles and is considered as a very sensitive and specific neuroendocrine marker [23]. Chromogranin A, marker of neuroendocrine granules according to Parka et al., and Hamady et al., is a very sensitive marker of neuroendocrine cells [24, 25]. Aguirre et al. and Scully et al., isolated three types of granules in those carcinomas, two types with neuroendocrine character and the third type was connected with the secretion of polypeptide hormones (calcitonin, gastrin, somatosta- tin, ACTH, neurotensin and others) $[3,6]$. NSE, a cytosolic marker, is a neural form of glycolytic enzymes and is positive in most neuroendocrine carcinomas. Nesland et al. demonstrated that positive immunoreaction for NSE does not always demonstrate the real presence of neuroendocrine cells [26]. Due to various specificities of neuroendocrine markers, it seems that recognition of that type of cancer should be supported by at least two additional immunohistochemical tests.

In the 12 endometrioid cancers we examined, the presence of neuroendocrine cells immunopositive only on chromogranin A was noted, and they were included to DES. They did not form cancer nests, but were individually incorporated in epithelium of cancer glandular cells (Figure 3). Similar cells were found in normal endometrium, in pathological hyperplasia and in endometrium of fetal uterus. These are the same cells of APUD type, which in older papers were identified using silver impregnation (the Grimelius method). The presence of similar cells with similar localization has been described by numerous authors (27).

Aguirre et al. studied those cells immunohistochemically and by using an electron microscope. They demonstrated some interdependence between silver-stained granules and the presence of glycogen grains or mucin. For example, treatment of tissue slides with diastase caused the disappearance of glycogen and argyrophilia [3].

This is the first paper in the Polish literature demonstrating material about endometrial cancers. It concerns undifferentiated cancers and mixed cancers positive for neuroendocrine markers without a typical morphological pattern. This phenomenon needs further study on a larger amount of material and with more precise biological analysis. The presented results do not allow the drawing of overall conclusions.

These results indicate the necessity to determine neuroendocrine biomarkers by the immunohistochemical method in undifferentiated and mixed endometrial cancers. Immunopositive results indicate a higher malignancy of those cancers, and a necessity to expand treatment by chemotherapy.

\section{References}

1. Pearse AG. The cytochemistry and ultrastructure of polypeptide hormone-producing cells of the APUD series and the embryologic, physiologic and pathologic implications of the concept. J Histochem Cytochem. 1969;17:303-313.

2. Ueda G, Yamasaki M, Inoue M, Kurachi K. Ultrastructural demonstration of argyrophil nature of secretory granules in endometrial carcinomas with argyrophil cells. Acta Obstet Gynaecol Jpn. 1979; 31:519-520.

3. Aguirre P, Scully RE, Wolfe HJ, DeLellis RA. Endometrial carcinoma with argyrophil cells: a histochemical and immunohistochemical analysis. Hum Pathol. 1984;15:210-217. 
4. Ueda G, Yamasaki M, Inoue M et al. Calcitonin producing endometrial carcinomas demonstrated by immunohistology. Acta Obstet Gynaecol Jpn. 1978;30:1365-1366.

5. Abeler VM, Kjørstad KE, Nesland JM. Undifferentiated carcinoma of the endometrium. A histopathologic and clinical study of 31 cases. Cancer. 1991;68:98-105.

6. Scully RE, Aguirre P, DeLellis RA. Argyrophilia, serotonin, and peptide hormones in the female genital tract and its tumors. Int J Gynecol Pathol. 1984;3:51-70.

7. Huntsman DG, Clement PB, Gilks CB, Scully RE. Small-cell carcinoma of the endometrium. A clinicopathological study of sixteen cases. Am J Surg Pathol. 1994;18:364-375.

8. Van Hoeven KH, Hudock JA, Woodruff JM, Suhrland MJ. Small cell neuroendocrine carcinoma of the endometrium. Int J Gynecol Pathol. 1995;14:21-29.

9. Eichhorn JH, Young RH. Neuroendocrine tumors of the genital tract. Am J Clin Pathol. 2001;115(Suppl):S94-112.

10. Young RH, Oliva E, Scully RE. Small cell carcinoma of the ovary, hypercalcemic type. A clinicopathological analysis of 150 cases. Am J Surg Pathol. 1994;18:1102-1116.

11. Kędzia W, Bierła J, Kędzia H. Agressive variants of uterine cervical cancers. Ginek Pol. 2007;78:733-736.

12. Kędzia H. Small cell carcinoma of the ovary. Ginek Pol. 1994;65:146-152.

13. Mulvany NJ, Allen DG. Combined large cell neuroendocrine and endometrioid carcinoma of the endometrium. Int J Gynecol Pathol. 2008;27:49-57.

14. Tamura T, Jobo T, Watanabe J, Kanai T, Kuramoto H. Neuroendocrine features in poorly differentiated endometrioid adenocarcinomas of the endometrium. Int J Gynecol Cancer. 2006;16:821-826.

15. Posligua L, Malpica A, Liu J, Brown J, Deavers MT. Combined large cell neuroendocrine carcinoma and papillary serous carcinoma of the endometrium with pagetoid spread. Arch Pathol Lab Med. 2008;132:1821-1824.

16. Shaco-Levy R, Manor E, Piura B, Ariel I. An unusual composite endometrial tumor combining papillary serous carci- noma and small cell carcinoma. Am J Surg Pathol. 2004;28:1103-1106.

17. Cetiner H, Kir G, Akoz I, Gurbuz A, Karateke A. Large-cell neuroendocrine carcinoma of the cervix associated with cervical-type invasive adenocarcinoma: a report of case and discussion of histogenesis. Int J Gynecol Cancer. 2006;16:438-442.

18. Creasman WT, Odicino F, Maisonneuve P et al. Carcinoma of the corpus uteri. Twenty Fifth Annual Report on the Results of Treatment in Gynecological Cancer. Int J Gynaecol Obstet. 2003;83(Suppl 1):S98.

19. Tohya T, Miyazaki K, Katabuchi H, Fujisaki S, Maeyama M. Small cell carcinoma of the endometrium associated with adenosquamous carcinoma: a light and electron microscopic study. Gynecol Oncol. 1986;25:363-371.

20. Gersell DJ, Mazoujian G, Mutch DG, Rudloff MA. Smallcell undifferentiated carcinoma of the cervix. A clinicopathologic, ultrastructural, and immunocytochemical study of 15 cases. Am J Surg Pathol. 1988;12:684-698.

21. Hashimoto T, Morimura Y, TakanoY et al. A case of small cell neuroendocrine carcinoma of uterine corpus origin coexistended with endometrioid adenocarcinoma. J Jab Soc Gynecol Oncol. 2000;18:253-256.

22. Wicha MS, Liu S, Dontu G. Cancer stem cells: an old idea-a paradigm shift. Cancer Res. 2006; 66:1883-1890.

23. Gould VE, Wiedenmann B, Lee I et al. Synaptophysin expression in neuroendocrine neoplasms as determined by immunocytochemistry. Am J Pathol. 1987;126:243-257.

24. Park JG, Choe GY, Helman LJ et al. Chromogranin-A expression in gastric and colon cancer tissues. Int J Cancer. 1992;51:189-194.

25. Hamada Y, Oishi A, Shoji T et al. Endocrine cells and prognosis in patients with colorectal carcinoma. Cancer. 1992; 69:2641-2646.

26. Nesland JM, Holm R, Johannessen JV, Gould VE. Neurone specific enolase immunostaining in the diagnosis of breast carcinomas with neuroendocrine differentiation. Its usefulness and limitations. J Pathol. 1986;148:35-43.

Submitted: 5 July, 2011

Accepted after reviews: 7 January, 2012 